\title{
SISTEM PENDUKUNG KEPUTUSAN PEMILIHAN PEGAWAI TERBAIK MENGGUNAKAN SIMPLE ADDITIVE WEIGHTING
}

\author{
Arfandi Ahmad ${ }^{1}$, Yogiek Indra Kurniawan*2 \\ ${ }^{1,2}$ Informatika, Fakultas Teknik, Universitas Jenderal Soedirman, Indonesia \\ Email: ${ }^{1}$ arfandi.ahmad@ mhs.unsoed.ac.id, ${ }^{2 *}$ yogiek@ unsoed.ac.id
}

(Naskah masuk: 12 Juli 2020, diterima untuk diterbitkan: 07 Agustus 2020)

\begin{abstract}
Abstrak
Dalam suatu perusahaan yang berkembang, apresiasi pegawai sangat dibutuhkan untuk meningkatkan moral dan kinerja. Penilaian yang akurat dibutuhkan untuk dapat menunjuk pegawai terbaik. Namun, penilaian akan menjadi lebih kompleks seiring dengan bertambahnya pegawai dan beragamnya komponen penilaian. Pada $C V$. Jenderal Software, penilaian pegawai tersebut masih dilakukan secara manual, sehingga menjadikan proses penilaian kurang efektif dan efisien. Untuk memaksimalkan proses penilaian pegawai terbaik, Sistem Pendukung Keputusan Pemilihan Pegawai Terbaik merupakan suatu sistem yang dapat membantu dan memudahkan perusahaan dalam melakukan proses tersebut. Tujuan dari paper ini adalah untuk membuat sebuah sistem pendukung keputusan menggunakan algoritma Simple Additive Weighting untuk meningkatkan keakuratan, efisiensi, serta efektifitas sistematika penilaian pegawai yang terjadi pada perusahaan $C V$. Jenderal Software. Pengumpulan data dilakukan dengan observasi langsung serta wawancara kepada pengguna, yaitu pimpinan perusahaan. Data yang didapatkan kemudian diproses dan dianalisis sehingga dapat dijadikan dasar pembuatan sistem. Hasilnya, sistem dapat meningkatkan keakuratan, efisiensi, dan efektifitas proses. Hasil pengujian Blackbox menunjukkan bahwa system telah berjalan sesuai dengan yang diharapkan. Sedangkan dari hasil pengujian User Acceptance Test, didapatkan nilai preferensi 97,5\% dengan indikator "Sangat Baik" yang menunjukkan bahwa system tersebut sudah sesuai dan layak dipakai.
\end{abstract}

Kata kunci: Pemilihan pegawai terbaik, Simple Additive Weighting, Sistem Pendukung Keputusan

\section{DECISION SUPPORT SYSTEM FOR BEST EMPLOYEE SELECTION USING SIMPLE ADDITIVE WEIGHTING}

\begin{abstract}
In a growing company, employee appreciation is needed to improve morale and performance. An accurate assessment is needed to be able to appoint the best employees. However, the assessment will become more complex as employees increase and the components of the assessment vary. At CV. Jenderal Software, the employee appraisal is still done manually, making the assessment process less effective and efficient. To maximize the best employee appraisal process, the Best Employee Selection Decision Support System is a system that can help and facilitate the company in carrying out the process. The purpose of this paper is to create a decision support system using the Simple Additive Weighting algorithm to increase the accuracy, efficiency, and effectiveness of the systematic employee appraisal that occurs in the CV Jenderal Software. Data collection was carried out by direct observation and interviews with users, namely company leaders. The data obtained is then processed and analyzed so that it can be used as the basis for making the system. As a result, the system can improve the accuracy, efficiency, and effectiveness of the process. Blackbox test results show that the system has been running as expected. Meanwhile, from the results of the User Acceptance Test, a preference value of $97.5 \%$ was obtained with the indicator "Very Good" which indicates that the system is appropriate and suitable for use.
\end{abstract}

Keywords: Best Employee Selection, Decision Support System, Simple Additive Weighting.

\section{PENDAHULUAN}

Dalam pemilihan keputusan perusahaan, suatu HRD atau pemimpin yang memutuskan suatu masalah tersebut. Namun dalam pemilihan keputusan tersebut, suatu HRD atau pemimpin tidak dapat secara cepat mengambil keputusan dikarenakan perlu mengkaji masalah tersebut lebih mendalam. Seiring 
perkembangan teknologi, terutama teknologi komputer yang mampu mengumpulkan, menyimpan, mengolah, menyebarkan, dan memberdayakan informasi yang meliputi bidang IPTEK dan merekayasakan sistem dapat menjadi solusi yang cepat dan tepat dalam mendukung keputusan perusahaan.

$C V$ Jenderal Software merupakan perusahaan pengembang software yang terletak di Sokaraja, Jawa Tengah. Dalam proses pemilihan keputusan pegawai terbaik, CV Jenderal Software masih melakukannya secara manual yang menyita banyak waktu. Selain itu, beragamnya parameter penilaian menyebabkan pengambilan keputusan semakin sulit dilakukan secara manual. Oleh sebab itu, dibutuhkan sebuah tools yang dapat membantu pimpinan untuk menentukan pemilihan pegawai terbaik secara lebih cepat dan akurat berdasarkan parameter penilaian tertentu sehingga dapat lebih efektif, efisien dan meminimalisasi kesalahan dalam pelaksanaannya.

Sistem Pendukung Keputusan (SPK) adalah sebuah tools yang digunakan untuk membantu pengambil kebijakan dalam menentukan keputusan berdasarkan parameter-parameter tertentu[1], [2]. Sistem pendukung keputusan dapat digunakan untuk menilai objek-objek tertentu dan mendapatkan nilai diskrit dari objek tersebut sehingga dapat dilakukan perankingan untuk mendapatkan objek terbaik[3][5].

Simple Additive Weighting (SAW) menjadi algoritma yang sudah terbukti dapat digunakan untuk sistem pendukung keputusan di berbagai kasus[6][11]. Penggunaan Simple Additive Weighting dapat menjadi solusi dalam pengambilan keputusan yang lebih cepat dan efisien.

Penelitian ini bertujuan untuk membuat sebuah sistem pendukung keputusan menggunakan algoritma Simple Additive Weighting untuk meningkatkan keakuratan, efisiensi, serta efektifitas sistematika penilaian pegawai yang terjadi pada perusahaan $C V$. Jenderal Software.

\section{METODE PENELITIAN}

Metode penelitian yang dilakukan pada paper ini terbagi menjadi beberapa tahapan berurut sebagai berikut :

\subsection{Identifikasi Masalah}

Melakukan identifikasi pada suatu masalah merupakan tahap awal pada proses penelitian. Tahap ini dibangun berdasarkan rumusan masalah yang didasari atas latar belakang masalah[12]. Selain itu, pada tahap ini dilakukan identifikasi terhadap sistem baik kebutuhan data, perangkat keras, maupun perangkat lunak.

\subsection{Studi Literatur}

Studi literatur digunakan dengan mempelajari dan memahami teori-teori yang digunakan, yakni diantaranya mencari faktor-faktor yang menjadi syarat Sistem Pendukung Keputusan dan Metode Simple Additive Weighting (SAW). Data-data tersebut dicari dengan mengumpulkan literatur, jurnal nasional, browsing internet dan bacaan-bacaan yang ada kaitannya dengan topik baik berupa teks ataupun paper mengenai algoritma Simple Additive Weighting[13].

SAW merupakan salah satu metode yang digunakan pada Sistem Pendukung Keputusan. Konsep dasar metode SAW adalah mencari penjumlahan terbobot dari rating kinerja pada setiap alternatif pada semua atribut. Metode SAW dapat membantu dalam pengambilan keputusan suatu kasus, akan tetapi perhitungan dengan menggunakan metode SAW ini hanya yang menghasilkan nilai terbesar yang akan terpilih sebagai alternatif yang terbaik. Perhitungan akan sesuai dengan metode ini apabila alternatif yang terpilih memenuhi kriteria yang telah ditentukan. Metode SAW ini lebih efisien karena waktu yang dibutuhkan dalam perhitungan lebih singkat. Metode SAW membutuhkan proses normalisasi matriks keputusan (X) ke suatu skala yang dapat diperbandingkan dengan semua rating alternatif yang ada.

Adapun langkah-langkah yang dapat dilakukan dalam SAW adalah :

a. Menentukan kriteria-kriteria yang akan dijadikan acuan dalam pengambilan keputusan, yaitu $\mathrm{Ci}$

b. Menentukan bobot alternatif pada setiap kriteria.

c. Membuat matriks keputusan berdasarkan kriteria (Ci)

Tahap ini kita akan melakukan normalisasi matriks berdasarkan persamaan yang disesuaikan dengan jenis atribut (atribut keuntungan atau atribut biaya) sehingga diperoleh matriks ternormalisasi R.

Rumus algoritma SAW dapat ditunjukkan oleh persamaan (1)[14].

$r_{i j}=\left\{\begin{array}{l}\frac{x_{i j}}{\operatorname{Max}_{i j}} \text { jika jadalah atribut keuntungan (benefit) } \\ \frac{\operatorname{Min}_{i} x_{i j}}{x_{i j}} \text { jika jadalah atribut biaya (cost) }\end{array}\right.$

Keterangan :

$\mathrm{R}_{\mathrm{ij}}$ : nilai rating kinerja ternormalisasi.

$\mathrm{X}_{\mathrm{ij}}$ : nilai atribut yang dimiliki setiap kriteria

$\operatorname{Max}_{\mathrm{i}} \mathrm{X}_{\mathrm{ij}}$ : nilai terbesar dari setiap kriteria

$\operatorname{Min}_{\mathrm{i}} \mathrm{X}_{\mathrm{ij}}$ : nilai terkecil dari setiap kriteria

Benefit : jika nilai terbesar adalah terbaik

Cost : jika nilai terkecil adalah terbaik.

Dimana $R_{i j}$ adalah rating kinerja ternormalisa si dari alternatif $A_{i}$ pada atribut $C_{j} ; i=1,2, \ldots, m$ dan $\mathrm{j}=1,2, \ldots, \mathrm{n}$. Nilai preferensi $\left(\mathrm{V}_{\mathrm{i}}\right)$ diberikan dengan rumus persamaan (2): 


$$
\mathrm{Vi}=\sum_{j=1}^{n} \mathrm{w}_{j} r_{i j}
$$

Nilai $V_{i}$ yang lebih besar mengindikasikan bahwa alternatif $\mathrm{A}_{\mathrm{i}}$ lebih terpilih.

\subsection{Pengumpulan Data}

Tahap ini merupakan cara mengumpulkan data yang dilakukan dengan 2 cara, yaitu observasi dan wawancara kepada pihak CV. Jenderal Software terkait pemilihan pegawai terbaik di CV. Jenderal Software.

\subsection{Analisis Data}

Setelah tahap pengumpulan data, selanjutnya melakukan analisis data spasial yang dikembangkan berdasarkan studi literatur yang dipahami dan dipelajari adalah cara menentukan pemilihan pegawai terbaik pada CV. Jenderal Software dengan menggunakan metode Simple Additive Weighting (SAW).

Berdasarkan hasil penelitian baik dari observasi maupun wawancara didapat kriteria-kriteria yang digunakan untuk parameter penilaian pemilihan pegawai terbaik. Berikut perincian persentase pada kriteria-kriteria:

\section{Benefit}
a. Tanggung Jawab
$: 30 \%$
b. Kemampuan
$: 20 \%$
c. Taat Peraturan
$: 10 \%$
Cost:
d. Mangkir (Absen) : $20 \%$
e. Keterlambatan Pengerjaan : $20 \%$

\subsection{Desain Sistem}

Setelah tahap analisis selesai dilakukan, berikutnya adalah tahap desain sistem. Tahap ini merancang model dan alur pengembangan sistem pendukung keputusan pemilihan pegawai terbaik sesuai dengan analisis yang telah dilakukan.

\subsection{Implementasi Metode SAW}

Setelah desain dirancang, tahap selanjutnya adalah proses pembuatan aplikasi. Pada tahap ini proses hasil desain yang telah dibuat diimplementasikan

Dalam tahap ini dilakukan dengan menggunakan metode SAW, yang pada prinsipnya melakukan perhitungan dengan mencari penjumlahan terbobot dari rating kinerja pada setiap alternatif pada semua atribut.

Langkah berikutnya yaitu implementasi ke dalam sistem. Pembuatan sistem ini menggunakan bahasa HTML dengan PHP framework Code Igniter. Pengembangan sistem ini menggunakan metode waterfall.

\subsection{Pengujian Sistem}

Setelah sistem berhasil dibuat berikutnya adalah pengujian sistem pendukung keputusan pemilihan pegawai terbaik. Pengujian ini dilakukan dengan menguji metode Simple Additive Weighting (SAW) pada hasil penilaian yang berisikan nilai-nilai subkriteria.

\section{HASIL DAN PEMBAHASAN}

Tahapan ini berupa desain, implementasi dan pengujian.

\subsection{Desain Sistem}

Metode yang digunakan pada desain sistem adalah Unified Modeling Language (UML), yakni: Use Case Diagram, Sequence Diagram, Class Diagram, dan Schema Diagram

\section{a. Use Case Diagram}

Use Case Diagram dapat menunjukkan fitur dan fungsionalitas dari system yang dibuat. Use Case Diagram dari SPK dengan algoritma SAW dapat ditunjukkan oleh gambar 1 .

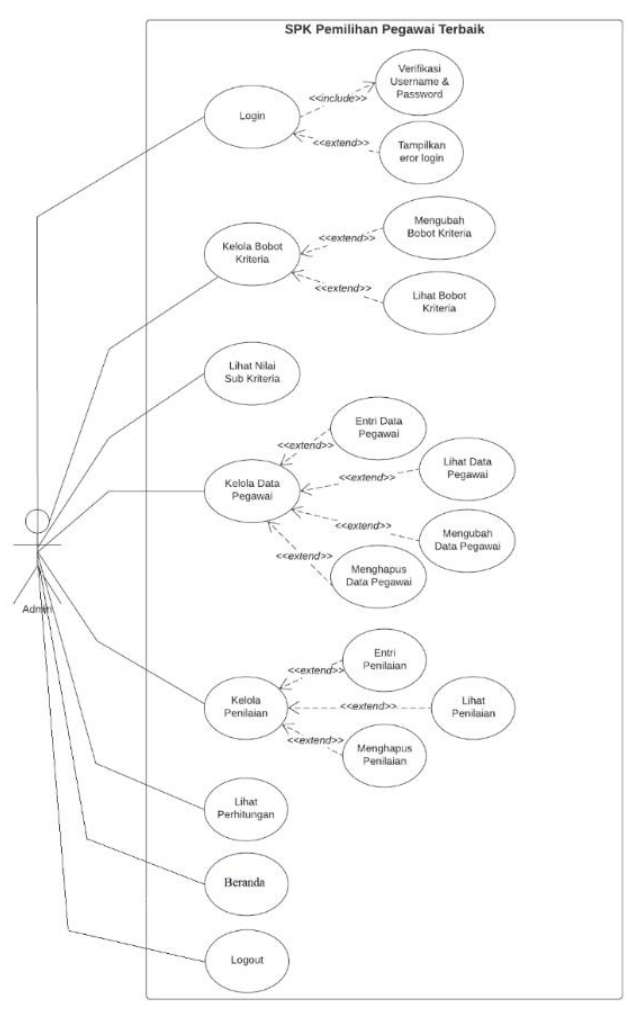

Gambar 1. Use Case Diagram

Pada Use Case Diagram tersebut, terdapat beberapa fitur utama, antara lain : Login, Kelola Bobot Kriteria, Lihat Nilai Sub Kriteria, Kelola Data Pegawai, Kelola Penilaian, Lihat Perhitungan, Beranda, dan Logout.

\section{b. Sequence Diagram}

Sequence Diagram menunjukkan alur dari sistem pada setiap fungsionalitas. Pada desain ini, 
dibuat 5 buah sequence diagram, yaitu sequence diagram bobot kriteria, sequence diagram nilai sub kriteria, sequence diagram pegawai, sequence diagram penilaian dan sequence diagram untuk perhitungan. 5 Buah sequence diagram tersebut dapat ditunjukkan oleh gambar 2, gambar 3, gambar 4, gambar 5 dan gambar 6 .

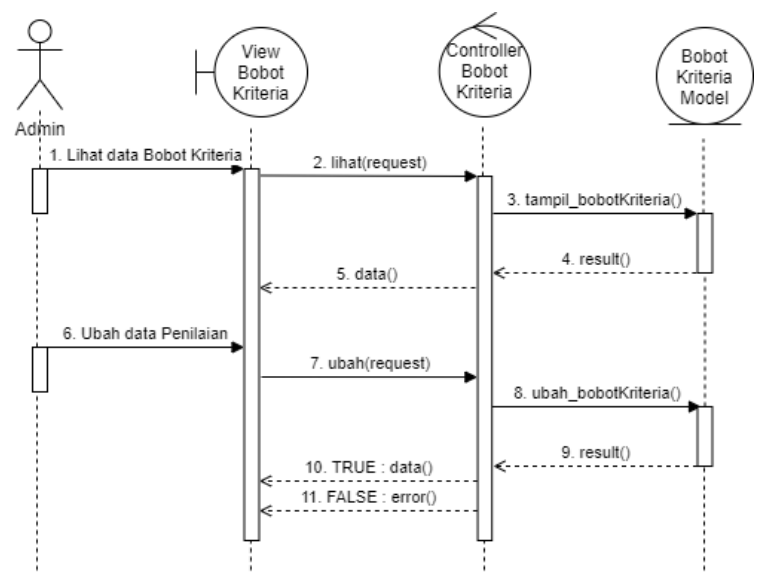

Gambar 2. Sequence Diagram Bobot Kriteria

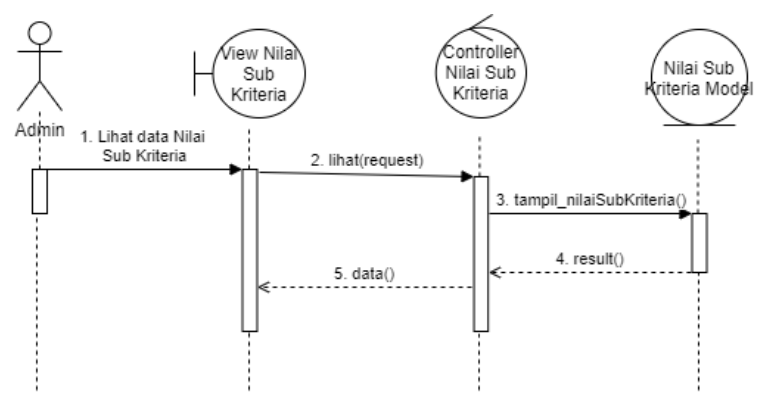

Ganbar 3. Sequence Diagram Nilai Sub Kriteria

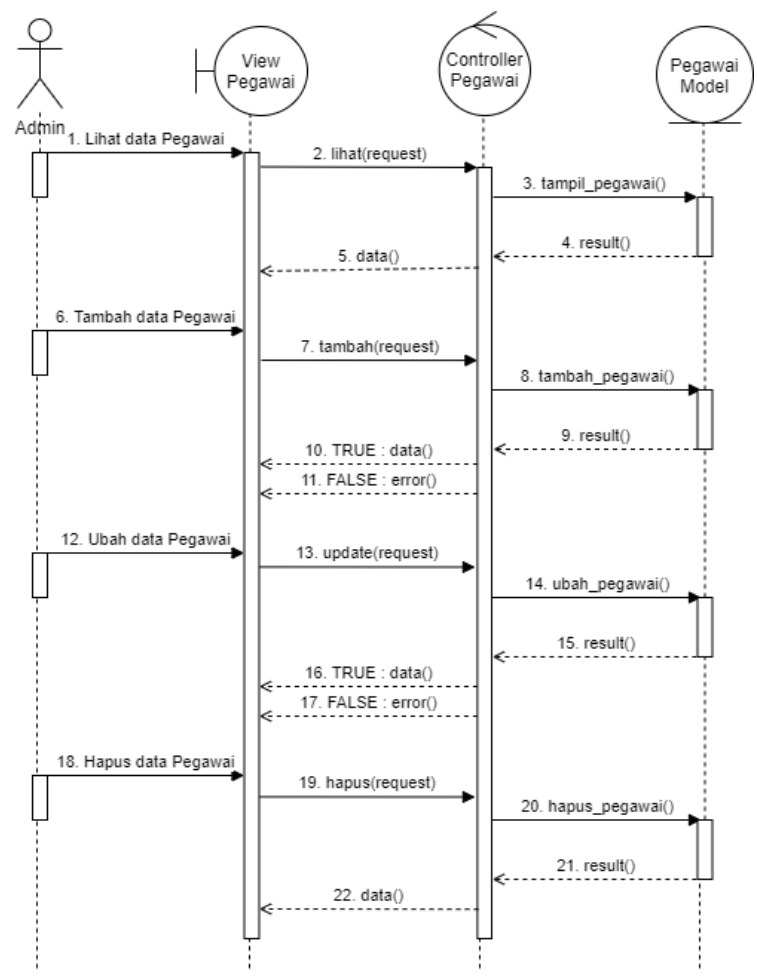

Gambar 4. Sequence Diagram Pegawai

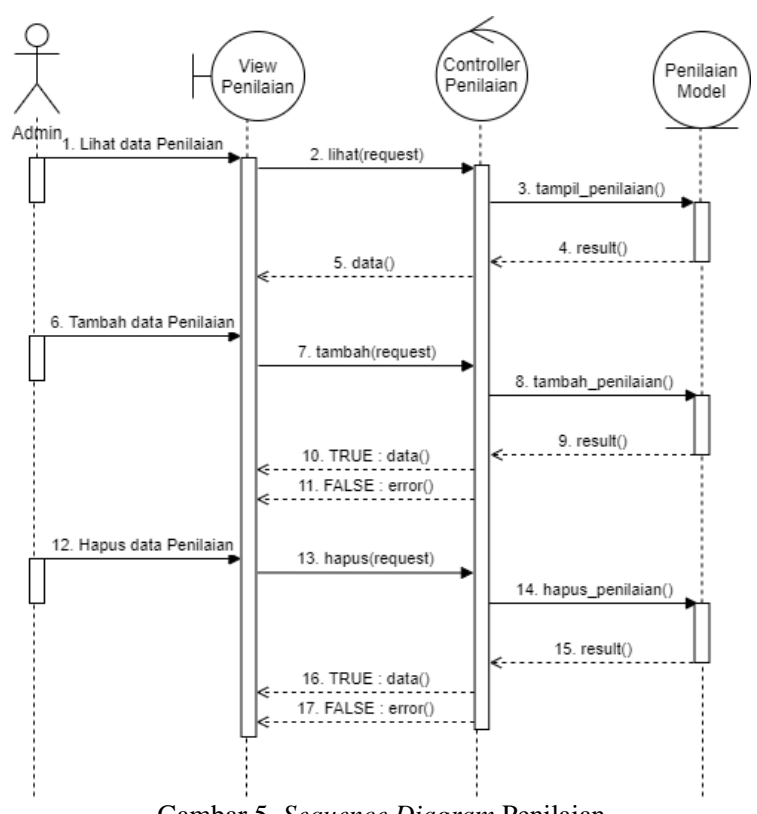

Gambar 5. Sequence Diagram Penilaian

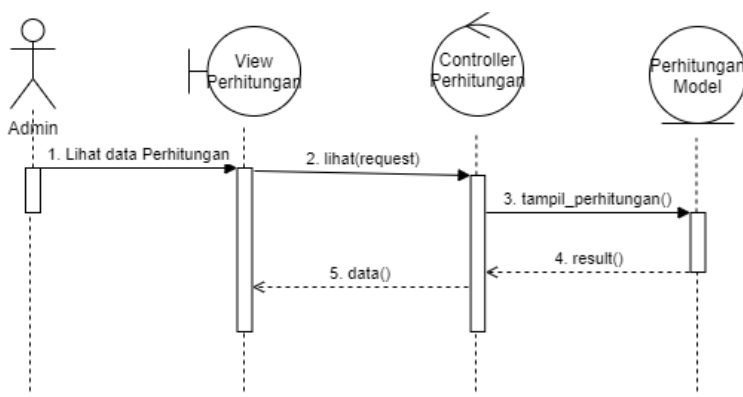

Gambar 6. Sequence Diagram Perhitungan

\section{c. Class Diagram}

Class Diagram dapat menunjukkan class yang terbentuk pada saat implementasi program. Pada class diagram, terbentuk 7 buah class termasuk class Main. Class lain yang terbentuk adalah class login, class perhitungan, class bobotKriteria, class NilaiSubKriteria, class pegawai, dan class penilaian. Setiap class berhubungan antara satu dengan yang lainnya. Class Diagram yang terbentuk dapat ditunjukkan oleh gambar 7.

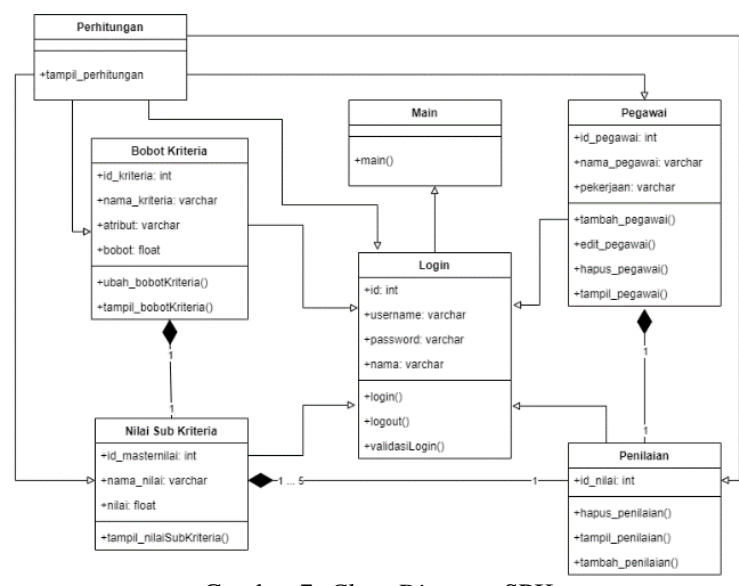

Gambar 7. Class Diagram SPK 


\section{d. Schema Diagram}

Schema Diagram dapat menunjukkan database yang terbentuk pada saat pembuatan program. Schema Diagram pada aplikasi SPK dengan SAW ini dapat ditunjukkan oleh gambar 8.
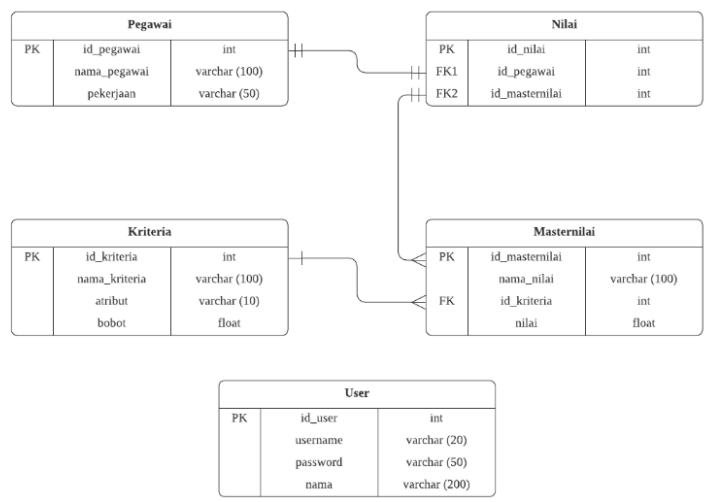

Gambar 8. Schema Diagram SPK PPT

\subsection{Implementasi Sistem}

Berikut ini adalah tampilan dari sistem yang sudah didesain. Dimulai dari halaman login, lalu masuk ke halaman beranda. Fitur-fitur yang ada pada sistem ini adalah kelola bobot kriteria, nilai sub kriteria, kelola pegawai, kelola penilaian, dan hasil perhitungan. Pada fitur kelola terdapat form seperti form tambah dan form edit.

a. Tampilan Halaman Login

Halaman login merupakan halaman yang pertama kali muncul ketika aplikasi dibuka. Tampilan halaman login dapat ditunjukkan oleh gambar 9 .

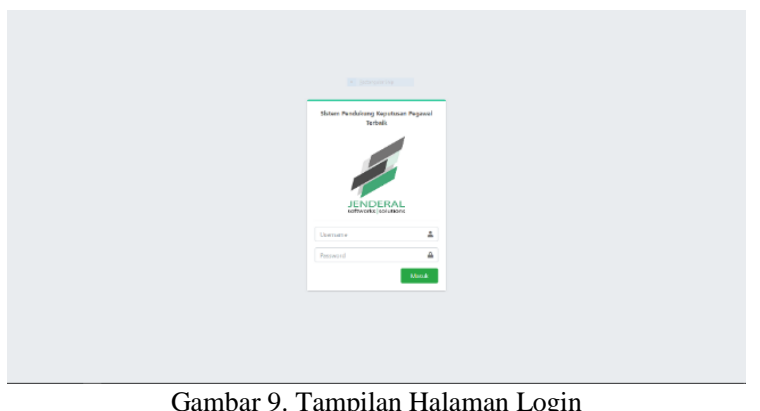

b. Tampilan Halaman Beranda

Halaman beranda merupakan halaman yang nantinya muncul ketika user sudah berhasil login. Pada aplikasi ini hanya terdapat 1 buah user, yaitu admin. Tampilan halaman beranda dapat ditunjukkan oleh gambar 10.

\section{c. Tampilan Bobot Kriteria}

Pada aplikasi ini terdapat menu untuk mengatur bobot kriteria. User dapat melakukan perubahan terhadap bobot pada setiap kriteria. Tampilan bobot kriteria dapat ditunjukkan oleh gambar 11. Sedangkan gambar 12 menunjukkan tampilan untuk perubahan bobot kriteria.

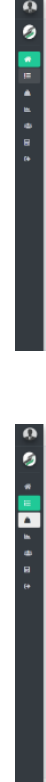

Gambar 10. Tampilan Halaman Beranda

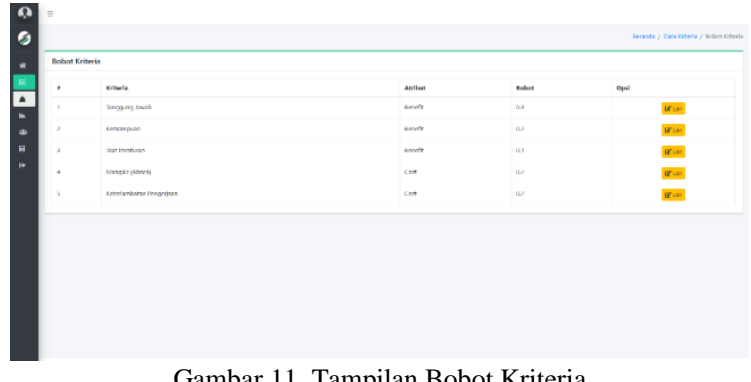

Gambar 11. Tampilan Bobot Kriteria

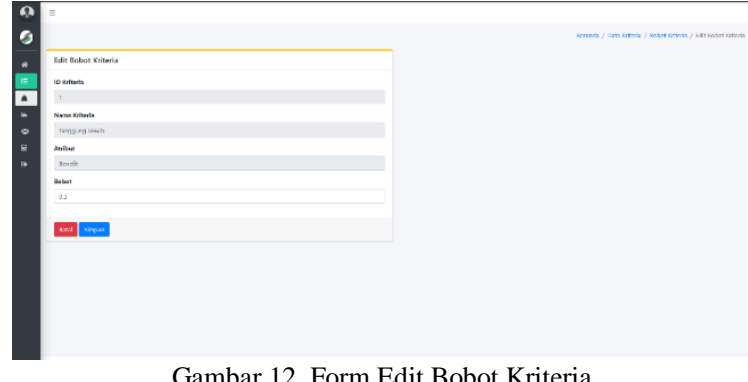

d. Tampilan Nilai Sub Kriteria

Aplikasi ini dapat menampilkan nilai dari setiap sub kriteria. Tampilan ini sebagai pedoman penilaian untuk membantu user dalam memberikan nilai. Tampilan nilai sub kriteria dapat ditunjukkan oleh gambar 13.

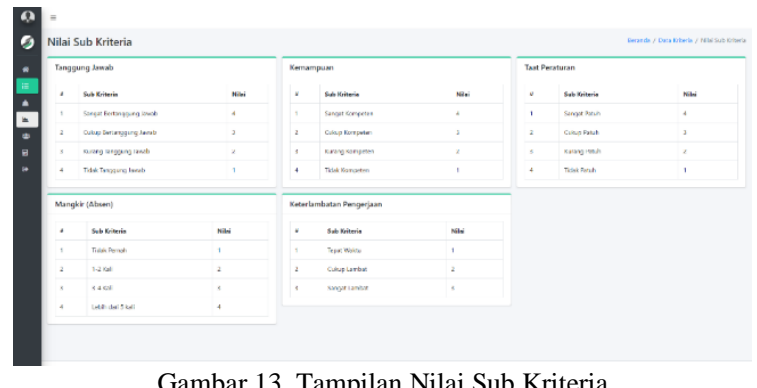

Gambar 13. Tampilan Nilai Sub Kriteria

e. Tampilan Daftar Pegawai dan Penilaian

Pada halaman Daftar Pegawai dan Penilaian ini terdapat data pegawai dengan opsi menambah, mengedit, dan menghapus data tersebut serta terdapat data penilaian dengan opsi menambah nilai dan menghapus nilai. Tampilan daftar pegawai dan penilaian dapat ditunjukkan oleh gambar 14. 


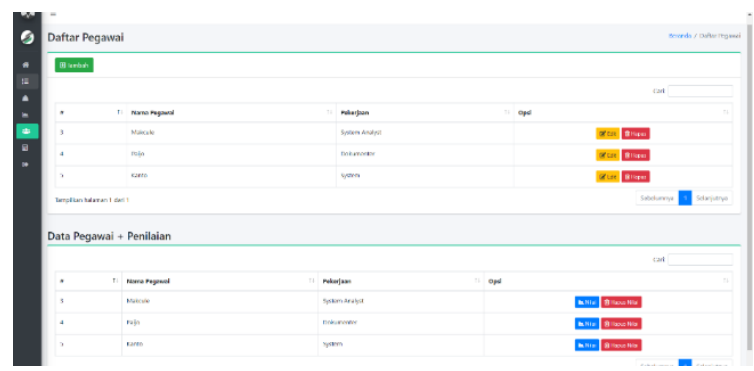

Gambar 14. Tampilan Daftar Pegawai \& Penilaian

f. Form Tambah Data Pegawai

Halaman Entri Data Pegawai merupakan halaman untuk menambahkan data pegawai berupa nama dan pekerjaan. Selain itu, data pegawai dapat juga diubah maupun dihapus. Tampilan untuk form tambah data pegawai dapat ditunjukkan oleh gambar 15 .

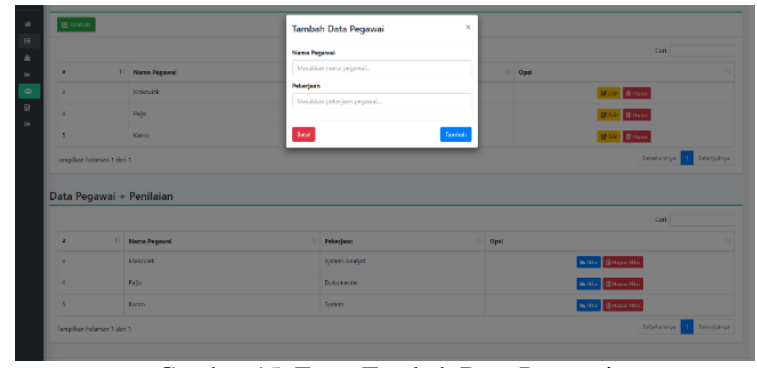

Gambar 15. Form Tambah Data Pegawai

g. Form Tambah Penilaian

Halaman Entri Penilaian merupakan halaman untuk menambah data penilaian. Pada halaman ini terdapat form input yang bisa memilih pilihan penilaian. Halaman entri dapat ditunjukkan oleh gambar 16. Setelah dilakukan penambahan data penilaian, maka data tersebut akan muncul seperti ditunjukkan oleh gambar 17 .

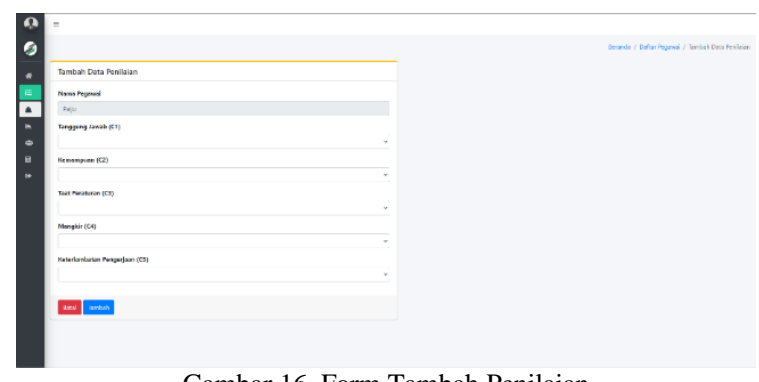

Gambar 16. Form Tambah Penilaian

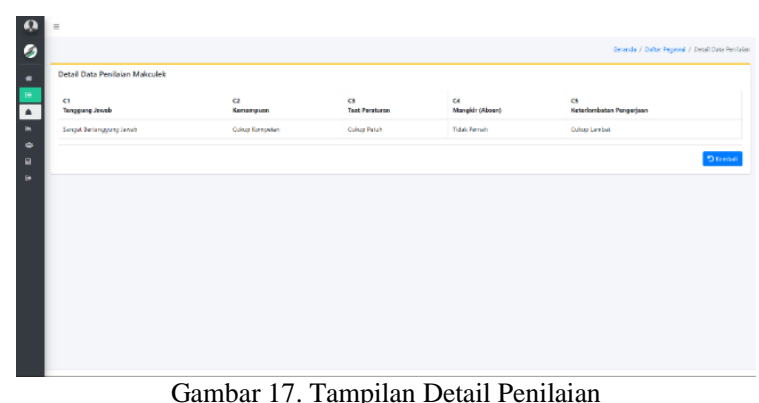

Gambar 17. Tampilan Detail Penilaian

\section{h. Tampilan Perhitungan}

Halaman Perhitungan merupakan halaman untuk melihat proses perhitungan dari pilihan nilai subkriteria yang sudah dipilih. Pada halaman ini menampilkan data penilaian pegawai, nilai dari data pegawai, hasil perhitungan normalisasi, dan nilai ranking akhir dari Normalisasi sehingga dapat dilihat pegawai dengan nilai terbaik.

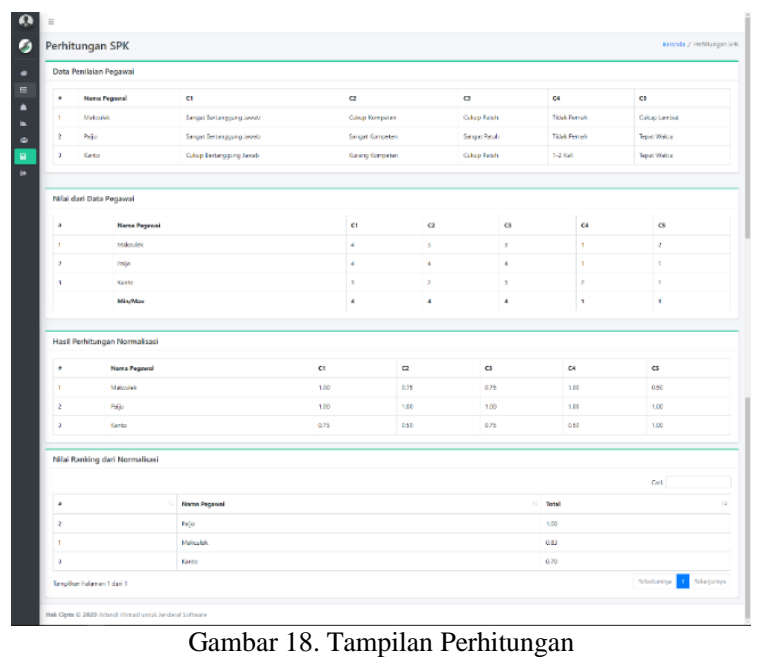

\subsection{Pengujian Sistem}

Pengujian yang dilakukan pada tahapan ini adalah pengujian blackbox dan pengujian User Acceptance Test.

Pengujian Blackbox adalah pengujian untuk mengetahui apakah fungsionalitas sistem dapat berjalan sesuai dengan yang diharapkan oleh pengembang aplikasi, tanpa melihat kode di dalam sistem tersebut[15]-[18]. Hasil pengujian Blackbox dari SPK dengan SAW yang telah dibuat dapat ditunjukkan oleh tabel 1 .

Tabel 1. Hasil Pengujian Blackbox

\begin{tabular}{|c|c|c|c|c|}
\hline No & Fitur & Input & Output & Status \\
\hline 1. & Login & $\begin{array}{l}\text { Memasukkan } \\
\text { Username dan } \\
\text { Password yang } \\
\text { benar }\end{array}$ & $\begin{array}{l}\text { Masuk ke dalam } \\
\text { system }\end{array}$ & Valid \\
\hline 2. & $\begin{array}{l}\text { Kelola Bobo } \\
\text { Kriteria }\end{array}$ & $\begin{array}{l}\text { Memasukkan } \\
\text { bobot kriteria }\end{array}$ & $\begin{array}{l}\text { Bobot kriteria } \\
\text { tersimpan ke } \\
\text { dalam database. }\end{array}$ & Valid \\
\hline 3. & $\begin{array}{l}\text { Lihat Nilai Sub } \\
\text { Kriteria }\end{array}$ & $\begin{array}{l}\text { Menekan } \\
\text { menu Nilai } \\
\text { Sub Kriteria }\end{array}$ & $\begin{array}{l}\text { Menampilkan } \\
\text { nilai sub kriteria }\end{array}$ & Valid \\
\hline 4. & $\begin{array}{l}\text { Kelola Data } \\
\text { Pegawai }\end{array}$ & $\begin{array}{l}\text { Input data } \\
\text { pegawai }\end{array}$ & $\begin{array}{l}\text { Data Pegawai } \\
\text { tersimpan }\end{array}$ & \\
\hline 5. & $\begin{array}{l}\text { Kelola } \\
\text { Penilaian }\end{array}$ & $\begin{array}{l}\text { Memasukkan } \\
\text { nilai pegawai }\end{array}$ & $\begin{array}{l}\text { Nilai Pegawai } \\
\text { tersimpan }\end{array}$ & \\
\hline 6. & $\begin{array}{l}\text { Lihat } \\
\text { Perhitungan. }\end{array}$ & $\begin{array}{l}\text { Menekan } \\
\text { menu } \\
\text { perhitungan }\end{array}$ & $\begin{array}{l}\text { Menampilkan } \\
\text { perhitungan } \\
\text { dengan SAW }\end{array}$ & \\
\hline 7. & Logout & $\begin{array}{l}\text { Menekan } \\
\text { tombol logout }\end{array}$ & $\begin{array}{l}\text { Keluar dari } \\
\text { sistem }\end{array}$ & Valid \\
\hline
\end{tabular}

Pengujian Blackbox ini dilakukan dengan melihat input dan output dari sistem. Jika output yang keluar sudah sesuai dengan yang diharapkan, 
maka fungsionalitas tersebut dinyatakan sebagai valid atau benar.

Berdasarkan hasil pengujian pada tabel 1, dapat diketahui, bahwa semua status berisi valid yang berarti bahwa sistem telah berjalan sesuai dengan yang diharapkan.

Pengujian berikutnya yang dilakukan adalah pengujian User Acceptance Testing (UAT). Pengujian UAT berisi pertanyaan kepada pengguna mengenai sistem yang telah dibuat untuk mengetahui persepsi pengguna terhadap sistem tersebut[19], [20].

Menurut [21] analisis angket pada aplikasi dilakukan dengan membandingkan jumlah skor perolehan dengan jumlah skor maksimal yang sudah ditetapkan dalam angket, seperti tertulis pada rumus (2).

$$
P=\frac{f}{N} x 100 \%
$$

Keterangan:

$\mathrm{P}=$ Skor persentase yang dicari

$\mathrm{f}=$ Perolehan skor oleh validator

$\mathrm{N}=$ Skor maksimal

Penilaian dari hasil pengujian didasarkan pada indikator degradasi kategori yang dapat diperlihatkan oleh tabel 2.

\begin{tabular}{cc}
\multicolumn{2}{c}{ Tabel 2. Indikator Kategori Penilaian } \\
\hline Nilai P & Kategori \\
\hline $0 \%-20 \%$ & Sangat Buruk \\
$20.01 \%-40 \%$ & Buruk \\
$40.01 \%-60 \%$ & Cukup \\
$60.01 \%-80 \%$ & Baik \\
$80.01 \%-100 \%$ & Sangat Baik \\
\hline
\end{tabular}

Hasil pengujian UAT dari pengumpulan kuesioner yang sudah diberikan kepada 5 responden dapat ditunjukkan oleh tabel 3.

Tabel 3. Hasil Pertanyaan

\begin{tabular}{|c|c|c|c|c|c|}
\hline No & Pertanyaan & SS & $\mathbf{S}$ & $\mathrm{KS}$ & TS \\
\hline \multirow[t]{2}{*}{ P1 } & $\begin{array}{l}\text { Apakah aplikasi ini } \\
\text { dapat mempermudah } \\
\text { pengambilan }\end{array}$ & 4 & 1 & 0 & 0 \\
\hline & $\begin{array}{lr}\text { keputusan } & \text { dalam } \\
\text { pemilihan } & \text { pegawai } \\
\text { terbaik? } & \end{array}$ & & & & \\
\hline P2 & $\begin{array}{l}\text { Apakah aplikasi ini } \\
\text { sudah sesuai dengan } \\
\text { penilaian pegawai } \\
\text { secara manual? }\end{array}$ & 5 & 0 & 0 & 0 \\
\hline
\end{tabular}

Tabel 4. Bobot Nilai Jawaban

\begin{tabular}{clc}
\hline No & \multicolumn{1}{c}{ Menu / Fitur } & $\begin{array}{c}\text { Hasil } \\
\text { Pengujial }\end{array}$ \\
\hline 1 & SS : Sangat : Mudah/Bagus/Sesuai/Jelas & 4 poin \\
2 & S : Mudah/Bagus/Sesuai/Jelas & 3 poin \\
3 & KS : Kurang : Mudah/Sesuai/Jelas & 2 poin \\
4 & TS : Tidak : Mudah/Bagus/Sesuai/Jelas & 1 poin \\
\hline
\end{tabular}

Tabel 5. Hasil Pengolahan Jawaban Responden

\begin{tabular}{cccc}
\hline No & Nilai f & Nilai P & Indikator Kategor \\
\hline P1 & 19 & $95 \%$ & Sangat Baik \\
P2 & 20 & $100 \%$ & Sangat Baik \\
Rata-Rata & 19,5 & $97,5 \%$ & Sangat Baik \\
\hline
\end{tabular}

Hasil uji UAT dikonversi dengan panduan bobot nilai jawaban yang dapat ditunjukkan oleh tabel 4.

Data yang didapat dari jawaban siswa diolah dengan cara mengalikan setiap jawaban pada tabel 3 dengan bobot yang ada pada tabel 4 .

Nilai maksimal $\mathrm{N}$ untuk kuesioner tersebut adalah sebesar 5 responden $\mathrm{x} 4$ poin $=20$ poin . Berdasarkan rumus (3), hasil dari perhitungan dengan mengalikan setiap jawaban dengan bobot maka didapat hasil sebagaimana ditunjukkan oleh tabel 5.

Dari hasil penilaian kuesioner pada tabel 5, rata-rata persentase nilai setiap pertanyaan mencapai angka 97,5\% dengan kategori "Sangat Baik". Hal ini menunjukkan Sistem Pendukung Keputusan dengan algoritma Simple Additive Weighting telah sesuai dan layak digunakan.

\section{KESIMPULAN}

Berdasarkan ide gagasan Sistem Pendukung Keputusan Pemilihan Pegawai Terbaik yang telah dijabarkan, maka dapat disimpulkan bahwa upaya yang dapat dilakukan mengefisienkan proses pemilihan pegawai terbaik pada CV. Jenderal Software dapat dilakukan dengan cara memanfaatkan peran teknologi, salah satunya dengan adanya Sistem Pendukung Keputusan menggunakan algoritma Simple Additive Weighting. Hasil pengujian Blackbox menunjukkan bahwa system telah berjalan sesuai dengan yang diharapkan. Sedangkan dari hasil pengujian User Acceptance Test, didapatkan nilai preferensi 97,5\% dengan indikator "Sangat Baik" yang menunjukkan bahwa system tersebut sudah sesuai dan layak dipakai.

\section{DAFTAR PUSTAKA}

[1] Y. I. Kurniawan and P. A. Windiasani, "Sistem Pendukung Keputusan Untuk Penentuan Kelolosan Beasiswa Sekolah Menengah Kejuruan (SMK) menggunakan Metode Fuzzy," J. Tek. Elektro, vol. 9, no. 1, pp. 13-17, 2017, doi: 10.15294/jte.v9i1.9322.

[2] D. Satiti and Y. I. Kurniawan, "Sistem Pendukung Keputusan Penentuan Jurusan SMA N 2 Sukoharjo Dengan Menggunakan Metode Fuzzy," in Seminar Nasional Geotik, 2017, pp. 234-241.

[3] N. A. Setiawan, P. A. Venkatachalam, and A. F. M. Hani, "Diagnosis of Coronary Artery Disease Using Artificial Intelligence Based Decision Support System," Proc. Int. Conf. Man-Machine Syst., no. October, pp. 1C3 11C3 5, 2009.

[4] Z. Qatawneh, M. Alshraideh, N. Almasri, L. Tahat, and A. Awidi, "Clinical decision support system for venous thromboembolism risk classification," Appl. Comput. 
Informatics, vol. 15, no. 1, pp. 12-18, 2019, doi: 10.1016/j.aci.2017.09.003.

[5] C. Mcwilliams, I. Gilchrist, M. Thomas, and R. Santos-rodriguez, "User-centric design of a clinical decision support system for critical care treatment optimisation User-centric design of a clinical decision support system for critical care treatment optimisation .," in 1st International 'Alan Turing' Conference on Decision Support and Recommender Systems, 2019, no. November, pp. 1-6, doi: 10.13140/RG.2.2.18770.09923.

[6] Y. I. Kurniawan, "Decision Support System for Acceptance Scholarship With Simple Additive," in International Conference on Science, Technology and Humanity, 2015, pp. 99-108.

[7] A. Fitrul Hadi, R. Permana, and H. Syafwan, "Decision Support System in Determining Structural Position Mutations Using Simple Additive Weighting (SAW) Method," J. Phys. Conf. Ser., vol. 1339, no. 1, 2019, doi: 10.1088/1742-6596/1339/1/012015.

[8] O. Sofian, J. Joseph, and F. Fauziyah, "Analysis of Decision Support System in Determining the Nutritional Status of Toddlers Using Simple Additive Weighting," CommIT (Communication Inf. Technol. J., vol. 14, no. 1, p. 9, 2020, doi: 10.21512/commit.v14i1.6069.

[9] B. A. rohman Eko Siswanto, "Sistem Informasi Pembayaran Tiket pada The Sea Pantai Cahaya Menggunakan Metode Simple Additive Weighting," Walisongo J. Inf. Technol., vol. 1, no. 1, pp. 25-34, 2019.

[10] S. Devi and H. T. S. Sihotang, "Decision Support Systems Assessment of the Best Village in Perbaungan sub-district with Simple Additive Weighting (SAW) Method," J. Mantik, vol. 3, no. 3, pp. 112-118, 2019.

[11] P. Ambika et al., "The best of village head performance: Simple additive weighting method," Int. J. Recent Technol. Eng., vol. 8, no. 2 Special Issue 3, pp. 1568-1572, 2019, doi: 10.35940/ijrte.B1286.0782S319.

[12] Y. I. Kurniawan, A. Rahmawati, N. Chasanah, and A. Hanifa, "Application for determining the modality preference of student learning," in Journal of Physics: Conference Series, 2019, vol. 1367, no. 1, pp. $1-11$, doi: 10.1088/17426596/1367/1/012011.

[13] Y. I. Kurniawan, E. Soviana, and I. Yuliana, "Merging Pearson Correlation and TANELR algorithm in recommender system," in AIP Conference Proceedings, 2018, vol. 1977, doi: 10.1063/1.5042998.

[14] R. H. Khouf and Y. I. Kurniawan, "Sistem Pendukung Keputusan Kelayakan Calon Penerima Bantuan Bedah Rumah Di
Kecamatan Sambirejo Dengan Menggunakan Metode Simple Additive Weighting," Universitas Muhammadiyah Surakarta, 2017.

[15] Y. I. Kurniawan and T. I. Barokah, "Klasifikasi Penentuan Pengajuan Kartu Kredit Menggunakan K-Nearest Neighbor," J. Ilm. Matrik, vol. 22, no. 1, pp. 73-82, 2020, doi: 10.33557/jurnalmatrik.v22i1.843.

[16] F. Y. Al Irsyadi, S. Supriyadi, and Y. I. Kurniawan, "Interactive educational animal identification game for primary schoolchildren with intellectual disability," Int. J. Adv. Trends Comput. Sci. Eng., vol. 8, no. 6, pp. 3058-3064, 2019, doi: 10.30534/ijatcse/2019/64862019.

[17] M. D. Taufikulloh and B. Wijayanto, "Sistem Informasi Manajemen Fasilitas Sertifikasi Halal, Hak Merek, Kemasan Produk Pelaku Usaha UMKM," J. Tek. Inform., vol. 1, no. 1, pp. 35-43, 2020.

[18] K. R. E. Septiani and F. Y. Al Irsyadi, "Game Edukasi Tari Tradisional Indonesia Untuk Siswa Tunarungu Kelas VI Sekolah Dasar," J. Tek. Inform., vol. 1, no. 1, pp. 7-12, 2020.

[19] F. Y. Al Irsyadi, A. P. Priambadha, and Y. I. Kurniawan, "Game Edukasi Bahasa Arab untuk Siswa Kelas IV di Sekolah Dasar Islam Terpadu Nahdlatul Ulama Cepgo," J. Manaj. Inform., vol. 10, no. 1, pp. 55-66, 2020, doi: doi: 10.34010/jamika.v10i1.

[20] F. Y. Al Irsyadi, D. Puspitassari, and Y. I. Kurniawan, "ABAS (Ayo Belajar Sholat) : Game Edukasi Pembelajaran Sholat Untuk Anak Tuna Rungu Wicara," J. Manaj. Inform., vol. 9, no. 1, pp. 17-28, 2019, doi: 10.34010/jamika.v9i1.1537.

[21] F. Y. Al Irsyadi, R. Annas, and Y. I. Kurniawan, "Game Edukasi Pembelajaran Bahasa Inggris untuk Pengenalan BendaBenda di Rumah bagi Siswa Kelas 4 Sekolah Dasar," J. Teknol. dan Inf., vol. 9, no. 2, pp. 78-92, 2019, doi: 10.34010/jati.v9i2.1844. 